\title{
Learning teamwork through a computer game: for the sake of performance or collaborative learning?
}

\author{
Elina Riivari ${ }^{1}$ (D) Marke Kivijärvi ${ }^{1} \cdot$ Anna-Maija Lämsä ${ }^{1}$
}

Accepted: 21 May 2021 / Published online: 1 June 2021

(c) The Author(s) 2021

\begin{abstract}
Our study examined using a computer-based learning game as a tool to facilitate teaching and learning teamwork skills. The game was applied to an undergraduate level human resource management course at a business school in Finland. We focused on students' experiences and key learning outcomes of collaborative learning of teamwork skills through the game, and our analysis highlighted two key features of learning outcomes. First, the computer-based learning game promoted students' self-reflection and evaluation of their individual team roles. Second, although the game taught students the importance of continuous information sharing in teamwork, their evaluation of team outcomes was performance driven; students predominantly took team efficiency as a sign of good teamwork. This case revealed the benefits and challenges of using computer-based learning games as a pedagogical tool. We identified what is required from lecturers and students for the game to be successful, and how team values other than performance could be learned through the game.
\end{abstract}

Keywords Higher education · Computer simulation game · Collaborative learning · Leadership · Teamwork skills

\section{Introduction}

Teamwork skills and collaborative competency are becoming increasingly important in student and professional life. Collaboration in teams is often a productive way to solve complex and nonroutine problems (Avry et al. 2020; Fiore et al. 2017). Businesses and organizations increasingly expect graduates to have excellent interaction, cooperation, problem-solving, and critical thinking skills (Cobo 2013; van Laar et al. 2020). To respond

Elina Riivari

elina.riivari@jyu.fi

Marke Kivijärvi

marke.t.kivijarvi@jyu.fi

Anna-Maija Lämsä

anna-maija.lamsa@jyu.fi

1 School of Business and Economics, University of Jyvaskyla, P.O. Box 35, 40014 Jyvaskyla, Finland 
to these demands, higher education has changed its focus from teacher-centric approaches to student participation and collaborative knowledge construction to equip students with the competencies required at work. This has led to an increasing use of group assignments (Kalfa \& Taksa 2017), as well as integrative pedagogy such as problem-based learning (Tynjälä \& Gijbels 2012). More recently, the pedagogical toolkit has been extended to the domain of game-based learning, which further engages students with cognitive, behavioral, and affective learning experiences (Vlachopoulos \& Makri 2017), and creates a constructive context for enhancing teamwork skills (Lohmann et al. 2019).

This study examined the use of a computer simulation game for teaching teamwork skills. There is a long tradition of using games as learning tools (see Cohen \& Rhenman 1961), particularly in management education, for which they have been used since the 1930s (Faria et al. 2008). Games have been found useful particularly for developing 21stcentury skills, such as critical thinking, collaboration, and creativity (Qian \& Clark 2016). According to Pasin and Giroux (2011), learning through gaming develops learners' decision-making capabilities for complex and rapidly changing management situations.

Previous research suggests that motivation and teamwork skills can be enhanced by implementing collaborative learning (Felder \& Brent 2003, 2004; Moreno et al. 2007), which highlights the importance of social interaction and shared responsibility for team learning and team outcomes (Dillenbourg 1999; Regueras et al. 2011). In addition, research has identified digital games as a means of collaborative learning (Hämäläinen 2011; Huo 2019; Karakas et al. 2015) and teaching teamwork skills (García et al. 2016). However, prior studies have called for further research on how collaborative learning and use of games can enhance learning of teamwork skills in the context of higher education (García et al. 2016; Hämäläinen 2011; Karakas et al. 2015). The computer-based simulation game therefore offers an interesting setting to explore the development of teamwork skills through collaborative learning.

The context of this study was an undergraduate human resource management (HRM) course at a business school in Finland, which employed a computer-based simulation game that was developed to teach teamwork skills based on collaborative learning. The game aimed to facilitate learners' ability to reflect on team roles and leadership functions for teamwork. The study sought to answer the following research question: What were the students' experiences and key learning outcomes of collaborative learning through a computer-based simulation game? In answering this question, our study examined how technology can be utilized in universities and identified critical aspects of using games in higher education.

\section{Learning teamwork skills through games}

Prior research shows that computer-based games support student learning (Feinstein 2001; Feinstein et al. 2002; Vlachopoulos \& Makri 2017) and provide a fruitful environment for collaborative learning (Wendel et al. 2013). Collaborative learning can be understood as an umbrella term for different types of educational approaches that center-stage students' own work on course materials and joint participation either through working in pairs or in small groups (Smith \& MacGregor 1992). In collaborative learning, learners construct a sense of shared meaning through interaction, and are typically committed to a shared goal (Littleton \& Häkkinen 1999). In collaborative learning, teams tend to be self-managed and include shifting in roles (Dillenbourg 1999; Sawyer \& Obeid 2017). In addition, in collaborative 
learning, learning is thought to be triggered through social interaction (Dillenbourg 1999). Collaborative learning is applied in higher education in multiple ways-for example, problem-solving in groups, debates, and other group activities (Wendel et al. 2013) — and highlights the importance of cooperation and shared learning (Johnson \& Johnson 1999). In collaborative learning, individual students help their team members achieve common team objectives (Regueras et al. 2011). Computer-supported collaborative learning has several benefits (Gašević et al. 2019): it can enhance critical thinking skills (Garrison et al. 2001) and creative potential (Dawson et al. 2011); create an enhanced sense of a community approach to learning (Dawson 2008); and increase students' integration into the learning community (Haythornthwaite 2002). Prior research has also recognized potential problems associated with collaborative learning (Yadin \& Or-Bach, 2019), such as students being unwilling to participate in team-based learning (e.g., Barker et al. 2002), and the potential for free riding (Joyce 1999), where team members enjoy the benefits of collaborative work without contributing as much as others.

Prior research in the field of collaborative learning through computer games has built on the principles of co-operative learning by Johnson and Johnson $(1999,2002)$ such as Zea et al. (2009) emphasizing the need to take the following five components into consideration when planning for collaborative learning; (1) positive interdependence, where students' understand that they cannot succeed alone but must depend on other team members; (2) individual accountability, where assessment of each student's performance relies on both the group and the student; (3) face-to-face interaction, which promotes the team's success by helping and encouraging others; (4) social skills, where interpersonal and group work skills are crucial to the success of a collaborative team effort; and (5) group processing, where team members discuss their progress and relationships together. For successful collaborative learning, it is important that the learning environments support these elements (Wendel et al. 2013).

As Kebritchi and Hirumi (2008) suggest, games are effective tools for learning complex topics, because they use action instead of explanation, create personal motivation and satisfaction, accommodate different learning styles and skills, reinforce expertise, and provide a context for interaction and decision making. The increased popularity of games in education may be related to their ability to achieve better learning outcomes and develop competencies for current and future working life (Kebritchi \& Hirumi 2008). Nevertheless, despite this increased popularity, it is not self-evident that their effects and outcomes are always superior to more traditional modes of learning; for example, the assumption of increased motivation and anticipation of higher learning outcomes have been challenged (Leemkuil \& De Jong 2012; Vandercruysse et al. 2012; Wouters et al. 2009). Moreover, research shows that more attention should be paid to the type and level of learner support (Leemkuil \& De Jong 2012).

As a form of thought-provoking activity, digital games especially influence enhanced student engagement, motivation, and satisfaction (Lohmann et al 2019; Regueras et al. 2011; Schindler et al. 2017). They are also useful training tools in management and leadership education for teaching decision making and strategy planning. Different forms of play and play spaces have become important for leadership training (Kark 2011). Games also offer a functional medium for developing cognitive capabilities needed to solve problems in real-life situations, helping to equip learners with information and skills for addressing these problems (Feinstein et al. 2002). Prior research has shown that business simulation games offer students opportunities to practice decision making and teamwork in authentic and complex situations (Lohmann et al. 2019; Pasin \& Giroux 2011). In addition, simulation games serve as useful platforms for developing leadership skills, particularly for 
exercising shared leadership (Siewiorek \& Lehtinen 2011; Siewiorek et al. 2013). Simulation games have been shown to be particularly effective in advancing students' understanding of leadership styles and changing their opinions on leadership styles (Siewiorek et al. 2013). Previous research also acknowledges the value of digital games in teaching teamwork skills (García et al. 2016).

In their review of employing games in higher education, Vlachopoulos and Makri (2017) emphasize the various positive effects of games on university students' cognitive, behavioral, and affective outcomes. Cognitive learning outcomes contribute to students' understanding of theoretical concepts and critical thinking; behavioral outcomes include the development of social, emotional, and collaborative skills; and affective outcomes refer, among other things, to student motivation and self-assessment (Vlachopoulos \& Makri 2017). Indeed, digital games have been recited as an effective means of collaborative learning (Hämäläinen 2011; Huo 2019; Karakas et al. 2015). However, there is a need to understand further how collaborative learning and use of games can enhance learning of teamwork skills in the context of higher education (García et al. 2016; Hämäläinen 2011; Karakas et al. 2015) and our study responds specifically to this research gap.

\section{Method}

\section{Study context}

The game was applied as part of an undergraduate level human resource management (HRM) course at a business school, which is a faculty, teaching, and research unit in one of the largest multidisciplinary research universities in Finland. The university has six faculties, around 2,600 employees, and approximately 15,000 students. The HRM course covers HRM history and schools of thought, strategic HRM, responsible HRM, HRM practices, organizational culture and change, leadership, teamwork, and employee relations. Around 80 students complete the course each year.

The learning game (which we describe in more detail below) was a mandatory component of the HRM course curriculum and proved to be a valuable addition to the course. Before including the game, the course consisted of lectures and mandatory group work (including an essay and a presentation). The traditional group work format was replaced by the learning game in 2013. The motivation to seek a new approach to group work was embedded with the observation that with traditional group work format, the students tended to follow the principles of co-operative learning by dividing work between members, each member producing their slice of the group work (Dillenbourg 1999). It was configured that a collaborative approach might be better suited for the purposes of teaching teamwork skills, because it essentially builds on social interaction and doing the work together (Dillenbourgh, 1999). The use of a computer game was considered a good replacement, because research findings strongly supported the use of computer-based games in student learning (Feinstein 2001; Feinstein et al. 2002). In addition, games enhance students' selfefficacy and improve learning and memorizing key concepts, especially when the game is embedded in the course curriculum and is an active part of the course material (Sitzmann 2011). A computer-based learning game was considered particularly suitable for teaching and developing teamwork skills in the course because it supported interaction and required teamwork among students, since it was played in real time and in teams. 


\section{Game description}

A commercial learning game, Novicraft, was selected for the course. Novicraft is a computer-based awareness game, designed particularly for team, leadership, and management training. The game was developed by a multidisciplinary research-based team, and its design was informed by learning and motivation theories. It offers an environment and tool for teamwork and interaction training and innovation development (Novicraft 2021).

The game takes place on an island where unpleasant guards watch over the teams. At the start of the game, the players are made aware of their mission: to escape from the island. The game is designed to require teamwork for successful completion; it uses scripts to assign team members with different resources (Hämäläinen 2011), requiring them to share knowledge and collaborate. Contribution from all team members is required to achieve objectives; there is no possibility of free riding to escape from the island as a team. The game consists of five tasks that the players must complete as a team and each task focuses on different types of teamwork, collaboration, and leadership skills.

The first task focuses on building trust within the team and considering others' opinions as one of the team members guides others, who cannot see anything, through a field. The second and third tasks focus on shared decision making, sharing information, and developing negotiation, collaboration, and coordination skills. For example, in the second task, the team needs to produce burner oil and the players must negotiate the right combination of ingredients. In the third task, one team member receives a map that guides the team in the right direction. If that team member does not share the information with other team members, it is very difficult or even impossible to complete the task.

In the fourth task, the team is required to take risks, and to plan and implement a strategy. The players must pass a field that is guarded by angry dogs and are required to develop a shared solution and help one another to pass the field. Staying safe from the dogs requires team members to build fences that keep the dogs away, which requires that team members communicate and coordinate the work together to decide where and when to build the fence to keep the dogs out. The final task involves planning and implementing a mini project within the team where they finally escape from the island with a vehicle, which they build together. The players are given each new task only after they have successfully completed the previous one. The game ends when the players complete the final task and win their freedom from the island because they worked successfully as a team.

Belbin's (1996) team roles form the theoretical basis of the game. The model includes both individual characteristics and functional skills. In playing the game, students will learn to identify and analyze their own and their team members' behavior and contributions based on Belbin's nine team roles: resource investigator, team worker (supporting and helping others), coordinator, plant (advancing new ideas), monitor evaluator, specialist, shaper, implementer, and completer finisher. According to Platt et al. (1988), various skills and team roles are needed for a team to achieve its objectives; therefore, each of these roles is essential for teamwork and team management (Launonen \& Kess 2002). In addition, the students learn to reflect on how team members perform different types of leadership functions to support and maintain effective teamwork (Kogler Hill, 2001; Northouse 2016). More specifically, Kogler Hill's 
(2001) team leadership model suggests that team leaders can monitor the team, and if necessary, decide to take action to help improve team performance. In the team leadership model, team leaders may choose from a range of task, relational and environmental leadership actions. These include actions such as clarifying goals and facilitating decision making (task), collaborating and building commitment (relational), and networking (environmental). In the game studied, the focus was on internal team leadership actions, that is on task and relational actions, rather than external actions in the environment. Before the game session, students were asked to read selected material relating to teamwork, team roles, and team leadership.

The game had the following learning objectives: (a) knowledge of the theoretical framework regarding team roles, decision making in teams, and internal leadership actions; (b) the ability to analyze different team roles; (c) the ability to analyze and reflect on one's own role as a team member; and (d) the ability to evaluate team effectiveness and decision making in a team.

\section{Playing the game and game facilitation}

The simulation game was played in a computer classroom according to the game developers' recommendations, with a maximum of 12 students (three to four teams of three to five players in each team) in each game session. The game developers considered the ideal team size to be four players. Following the developers' instructions for game facilitation, the students were seated in teams of three to five, each participant had their own computer, and team members could also interact face-to-face.

Two lecturers were trained to act as game facilitators who set up the game and acted as passive game instructors and observers during the game (e.g., giving instructions before starting the game, observing how the teams proceeded, and giving technical support during the game if needed). Following the game developers' recommendations, little facilitation occurred during the game. In the beginning of each game session, the facilitator explained that the purpose of the game was to foster learning teamwork skills and competencies, and highlighted the importance of teamwork, interaction, and communication in completing the game and its various problem-solving tasks. In addition, the facilitator presented a short technical introduction on how to play the game (how to create an avatar, use the game controls, etc.) before the start of the game and instructed students on how to play the game in their teams, emphasizing that they should focus only on their own computer screens and pay attention to the onscreen instructions. After initial preparations, the time reserved for actual playing was approximately two hours; all teams finished their game well within the reserved time.

While playing the game, students used various communication strategies and tactics to solve the problems included in the game setting. Although the facilitators instructed them to solve the problems by talking with one another, some of the students went further by shifting the position of their computer screens to show them to their team members when they encountered particularly challenging situations. At other times, some group members even walked by other teammates' computers to try to understand their problem or give advice in person. The facilitators mostly observed the students and only advised if requested. We noticed that most of the groups were enjoying the game, laughing and communicating in a relaxed manner. 


\section{Collection and analysis of student learning experiences}

The data for this study comprised written students' learning experiences that were collected online from each participant through semi-structured course feedback forms and written team reports (approximately one A4 page in length). The research material included 309 individual student feedback forms (2013: $N=79,2014: \mathrm{N}=78,2015: \mathrm{N}=78$, and 2016: $\mathrm{N}=74$ ) and 83 team reports (2013: $\mathrm{N}=22,2014: \mathrm{N}=21,2015: \mathrm{N}=21$, and 2016: $\mathrm{N}=19$ ). The feedback form and report focused on how the students interpreted the benefits and meaning of the game, learning outcomes, and challenges posed by the game.

The individual feedback form, where they analyzed their own perceptions and provided feedback on the gaming experience, was completed by students immediately after the team had successfully completed the game. It included nine open-ended questions (e.g., How would you describe your experiences after the game? How would you evaluate the gaming experience? What was the most difficult stage in the game in your opinion?). This was followed by a debriefing discussion within each team guided by the game facilitator.

After the group discussion, the facilitator asked each team to compile a team report relating to learning the teamwork skills where they evaluated team roles (both their own and those of their team members) and analyzed the team's effectiveness and decision making (e.g., how they performed their tasks, acted as a team, achieved their objectives, and succeeded in their actions). The theoretical background of the simulation game was based on learning and motivation theories, including Belbin's (1996) framework of team members' roles comprising nine team characters, and Kogler Hill's (2001) team leadership model that includes team performance and leadership functions to support and maintain effective teamwork. These frameworks formed the theoretical background for our analysis.

We analyzed students' individual feedback and their team reports using theory driven qualitative content analysis (Brymann \& Bell 2011; Hsieh \& Shannon 2005). Our analysis focused on three themes: (1) What kind of teamwork competencies did the students learn? (2) How did the students engage with collaborative learning? (3) What were the learning outcomes regarding team performance? First, we read through the material to get a holistic picture of the data. We then examined learning teamwork skills through Belbin's (1996) framework of teams and team roles, coding students' reflections based on the four key learning objective categories: (a) team roles, (b) decision making in teams, (c) internal team leadership actions (task and relational actions), and (d) team efficiency and success. Because the second and third categories overlapped, we discussed their findings together. Table 1 shows a summary of the key findings.

\section{Results}

\section{Students' experiences and key learning outcomes of the game}

\section{Team roles-advancing theoretical knowledge and self-reflection}

The game was well received by the students, who reported that it provided a welcome change to their regular study routine and teaching methods, and that they appreciated the game format as a refreshing alternative to traditional essays and lecture attendance. As one student commented, playing the game offered a "different and refreshing way 
Table 1 Key Findings

\begin{tabular}{|c|c|}
\hline Learning categories & Key learning outcomes \\
\hline Team roles & $\begin{array}{l}\text { The game simulation was successful in allowing the students to use } \\
\text { their theoretical knowledge to identify the different team roles in } \\
\text { practice, as well as to evaluate their own performance in a particular } \\
\text { team role }\end{array}$ \\
\hline $\begin{array}{l}\text { Decision making in teams and } \\
\text { internal team leadership actions }\end{array}$ & $\begin{array}{l}\text { The game simulation necessitated active participation of team members } \\
\text { The game was successful in making the students experience in practice } \\
\text { the importance of team interaction and communication: active sharing } \\
\text { of information was required to advance in the game } \\
\text { Team leadership was not assigned to one single person; rather, the teams } \\
\text { relied on shared leadership based on the individual team members' } \\
\text { possession of information and technological prowess } \\
\text { Team members with limited gameplay/technical experience at times } \\
\text { adopted a passive role }\end{array}$ \\
\hline Team efficiency and team success & $\begin{array}{l}\text { Team "purpose" and "success" were predominantly interpreted in terms } \\
\text { of fast gameplay, emphasizing victory over other teams and quick } \\
\text { problem solving } \\
\text { For the teams who took longer to finish the game, team spirit was a key } \\
\text { factor motivating them to continue playing }\end{array}$ \\
\hline
\end{tabular}

to learn about working in groups." The game was perceived to provide a more practical understanding than report writing. This finding is compatible with previous findings on the cognitive learning outcomes of games (e.g., Vlachopoulos \& Makri 2017). The students also reflected on the relevance of the game from the perspective of their learning:

Altogether, the game taught us interaction skills within the group context and concretized the concepts of team theories. I was able to see my own role in the group very clearly. Also, the pages I read for this class about team roles were concretized through the game. (Student 1)

The students also reflected on their own personal traits and the challenges these may impose on a team:

I am easily frustrated if I don't immediately understand something. I also get frustrated when I understand the issue myself but, when I try to explain it to others, they don't see it in the same way that I do. (Student 2)

The above quotation illustrates that the simulation game advanced the student's selfreflection of their personality and its possible impact on collaborating with others.

The most typical team roles identified by the students were the "plant" who advances new ideas, "coordinator," "implementer," and "team worker" (Belbin, 1996). In terms of team roles and leadership, it appeared that the students valued equality and participation, as illustrated in the following self-reflections:

I think that I operated pretty well in the team; I produced ideas and listened to others as well. (Student 3)

I followed orders and came up with some solutions myself. I succeeded pretty well at that. (Student 4) 
These examples show how the students, in addition to identifying specific team roles, learned to evaluate their own contribution as team members, emphasizing their ability both to resolve problems and respect others' viewpoints.

\section{Decision making in teams and internal team leadership actions-collaboration and shared leadership}

The students also reported that, in contrast to lectures where not everyone takes part, the game resulted in greater student participation. The game was perceived to foster "genuine" group work, whereas, in traditional group work formats, students often divide the tasks and complete them as individuals.

The idea of "forced collaboration" was positively appraised in several student feedback reports. According to one student, "These kinds of tasks force you to collaborate, which is good. You can only discover the plot of the game through active communication."

The students appreciated the fact that "you could not cope alone" and that you were "forced to collaborate with others." As another student phrased it, "You couldn't complete the game alone; you had to help others."

The idea of forced collaboration included the benefit that "it did not allow free riders." For example, collaboration was required to complete the first and fourth task in the game (see detailed task description on page 7). The game thus prevented social loafing because everyone could, and in fact had to, take part in the game. As one student put it, "You needed the others all the time in order to succeed." In analyzing students' learning experiences, the theme of communication was identified as the most important learning outcome.

The students reflected on their game experience in ways that clearly showed that they had internalized the importance of communication in successful teamwork. One student reported, for example, that it would be good to "plan more and hurry less." If given the opportunity to play the game again, one student reflected that they "would listen to others and emphasize the planning more in order to avoid us running around like headless chickens."

As seen in the above quotation, the student had learned that teamwork may benefit from sharing ideas and taking a more structured approach. Many of the students said that they would "read instructions more carefully and focus" and "think more carefully instead of rushing." This was the predominant idea: the need to spend more time thinking and planning.

One student admitted that "I could have told the others more specifically what I think, and what I consider to be the best course of action." Another student reflected along similar lines, stating that "The fourth task was the most challenging. It was very challenging to figure out the idea. Another team was able to find it sooner. It would have required communication." Here, the student acknowledges that communication is key to solving puzzles. This, coupled with the earlier student reflections, shows that the game helped the students understand the importance of collaborative learning, and to evaluate what collaborative learning requires from the participants for it to be realized in practice.

Regarding team leadership roles, students mainly described their teams as democratic; everybody was participating and "leading in turn." The following two quotations articulate the students' interpretation of how leadership roles were enacted in their teams depending on the situation:

Often, the person who possessed the required piece of information or tool, or a person who was the first to come up with the idea of the task at hand, served as a leader. 


\section{(Student 5)}

From our team, we could identify a number of roles, and they were shifting as we worked on different tasks. The roles changed depending on who was the first to come up with the correct implementation or solution and who began to lead the given task. (Student 6)

Students typically referred to the idea of someone "temporarily" taking the lead. However, they typically mentioned that there was usually one person who took the leadership role more seriously. As one student put it, "One [person] was perhaps the leader or the brain of the team. Someone who got us started." This quotation helps to illustrate that the students learned that roles were not stable but were positions that people could take during different phases of the teamwork.

Although most of the student feedback concentrated on the positive, collaborative aspects of the game, one theme addressed its potential drawbacks. The students referred to the influence of technical aptitude on the gaming experience and their participation in the joint group effort. When asked whether he had noticed the formation of group roles in his team, one student responded:

They may have been formed. Ellen (name changed) had no previous experience playing computer games, so she mostly just followed us, and she had to constantly be instructed. Mary (name changed) and I gave more instructions and resolved problems. (Student 7)

Another student recognized the limitations placed on one's own position as an equal team member because of technical challenges:

Yes, the younger team members were able to resolve problems more quickly, so I mainly operated based on their instructions. I would probably need more time to get used to operating with the mouse and the keyboard so that I could function better as a team member. In addition, we could plan ahead more carefully before acting. (Student 8)

The above quotations show how the adoption of a particular team role was partly related to one's technical aptitude (or lack thereof). Earlier studies have pointed out that more experienced players steer the less experienced ones through step-by-step guidance (Reich et al. 2013). Similarly, Zhang et al.'s (2017) analysis of intergenerational gameplay showed that younger players' instructions allow the older ones to take part as equal participants despite their lower technical skill levels.

\section{Team efficiency—for the sake of efficiency or collaborative learning?}

When the students were asked to describe their own views of what the team's task entailed, they gave a range of responses. While some students reported that their task was to "escape from the island and complete the game," others described the game as a task of "jointly solving the problems as a group and eventually escaping from the island." Only a smaller group of students referred to the task as one of "collaboration and joint communication."

For many students, the main task was, therefore, to "solve the problems as quickly as possible and to avoid making any mistakes," or as another student phrased it, "to pass the game as efficiently and as quickly as possible." The idea of speed as a sign of good teamwork was prevalent in students' feedback. When asked how they may have acted differently if given the opportunity to play the game again, one student said that "It went well; we 
were the first ones to finish," while another said that "I would play the game again more quickly."

Therefore, for some students the game was mostly about the teams' ability to display efficient gameplay. This illustrates the ambiguity in our data; although students reflected in retrospect on the importance of discussing different viewpoints and alternative courses of action (as we discussed in the theme above), their high valuation of speed offers a contradictory view of their experience.

However, some groups prioritized the importance of group spirit. Although the game lasted only about two hours, students reported that the team experience and their sense of being in a group helped them in the game. Overall, positive feedback on the game centered on the idea of group morale, which helped group members maintain their patience even when they had to struggle to find solutions:

Generally speaking, we are proud of our performance even though we were the last to finish. We did not get upset or panic even when we noticed that other teams were ahead of us. Our team spirit remained good throughout the game, and we supported each other in spite of the failures. Because of these good qualities, we were able to eventually finish the game. We did not give up at any point. We all think that playing the game alone would have frustrated us more quickly, and it wouldn't have made so much sense to play. (Student 9)

One student reported that you could "maintain your interest in the game because you didn't have to figure out things on your own."

One student reflected that they "used 'us' language" during the game. This illustrates that the game facilitated group formation and group identity. Humor (Hämäläinen 2011) was identified as a key means of maintaining a united team. As one student put it, "One aspect of building the cohesion of our team was humor. Through humor, we were able to make our adventure exciting, and it also inspired us to put our soul into the challenges."

Although students later reported that they should have spent more time planning their steps during the game, they recognized good team spirit as something that allowed them to bravely use trial-and-error-type strategies. According to one student, "We did not shy away from risks in situations where our game was stuck; we bravely tried the different solutions suggested by our team members."

The students also enjoyed the "fun" elements of the game and noted that playing the game made them experience the "joy of discovering things together." Overall, reflections on the game were positive, emphasizing how it provided "fun and a good brain-teaser," and stimulated challenges, while also providing enjoyment.

\section{Discussion}

This study examined how technology can be utilized in university pedagogy and identified critical aspects of using games, in particular, in higher education. In the following, we discuss how the study answered the research question: What were the students' experiences with, and key learning outcomes of collaborative learning through a computer-based simulation game? In order to answer this question, our analysis focused on examining what kind of teamwork competencies the students learned, how they engaged with collaborative learning, and what were the learning outcomes regarding team performance. Our study shows that the use of real time computer games offers a good alternative to the more 
traditional forms of teamwork, where students compile a group presentation on a selected topic, often with only minimal group interaction. The game allowed no room for free riding, a recognized pitfall of collaborative learning (Yadin \& Or-Bach, 2019), because each team member was required to contribute for the group to achieve its objectives (Lohmann et al. 2019). The game also highlighted the significance of sufficient communication and its link to team performance. The students' individual learning reflections revolved around realizing the centrality of knowledge sharing in teamwork (Lohmann et al. 2019). Interestingly, several students commented that it was a good thing that communication was "forced." Thus, we propose that game-like "forced" collaboration modes provide a good platform to show students how communication (or the lack thereof) affects team performance in practice (for similar findings, see Hämäläinen 2011). This also raises a question about the nature of our society. Finland is generally considered to be a very individualistic society (Hofstede 1980). Therefore, students' observations may reflect this social individualism, where sharing ideas and working as a team require an external stimulus. Future research could examine learning games in multicultural teams to address the communication patterns and learning experiences of students with different cultural backgrounds.

This study also highlighted the importance of face-to-face contact in teamwork. We witnessed the physical aspects of teamwork when, for instance, the students walked to each other's computers to demonstrate how to use the mouse to make a particular movement or to make a movement on behalf of their team member. They sometimes also turned their monitors around for others to see what was on their screen. Therefore, the students found additional ways of interacting with one another. Our research setting and game play design allowed us to reveal the physical nature of teamwork and demonstrate the benefits of faceto-face interaction in teams. However, considering that work is increasingly done in virtual contexts because of globalization and the rapid development of information and communications technology (Lähteenmäki et al. 2010), more research on virtual teams is needed. What kinds of problem-solving strategies would students develop if they are denied faceto-face communication?

Individual and team evaluations of success showed somewhat contradictory outcomes. At the individual level, students evaluated their own performance or success as a team member by two measures: their ability to problem-solve and their ability to listen to their teammates. Thus, for individuals to consider themselves good team workers, they believed they had to both contribute to solving tasks, and, importantly, possess good relational skills and consider other people's ideas. In other words, team members valued both relational skills and technical/problem-solving skills. These findings are consistent with previous research demonstrating that games contribute to students' learning and practicing collaboration skills and shared leadership (Siewiorek \& Lehtinen 2011; Siewiorek et al. 2013). In our study, improved communication was a key learning outcome for students. In this sense, our results correspond with those of Lohmann et al. (2019), who found a similar effect on team interaction.

However, our analysis of students' reflections revealed a strong performance orientation. Little value was placed on cooperative learning at the team level. Instead, students measured their team's efficiency mainly by the time it took to complete the game. As described above, many of the students interpreted their main objective as completing the game successfully in the shortest time possible. Although the students had been advised beforehand that speed was not the game's objective, we observed that they became frustrated when they believed that they were taking longer to complete tasks than they should. This emphasis on speed illustrates the inherent competitiveness of games. Even though competition can also have positive impacts, such as increased motivation to perform better 
(Vandercruysse et al., 2013), in the context of learning teamwork skills, competitiveness overrode collaborative learning.

\section{Pedagogical implications}

We assert that course instructors need to stress that efficiency is not necessarily the only goal in learning games and teamwork. Schwartzman (1997) noted that gaming is inherently associated with competition, and therefore proposes that interactional and collaborative aspects should be emphasized when the game metaphor is introduced into an educational context. From the perspective of management education, there is a risk that an efficient team is understood as one that accomplishes its tasks quickly. Given that the ability to integrate the diverse ideas, perspectives, and expertise of different team members is key to team innovation (van Knippenberg, 2017), we argue that there is a need to pay more attention to these aspects when using game simulations for developing teamwork. Although, as game facilitators we emphasized on several occasions that the game did not have a speed requirement, it would have been advisable to discuss the learning outcomes with the students in more detail after the game. Vandercruysse et al. (2013) have also pointed out that instructions given at the beginning of gameplay have little impact on students' perceptions of the learning environment. In addition, our findings indicate that educational technology has a central role in guiding the learning process, and we emphasize the need for a closer collaboration between educational game developers and pedagogical instructors in the future. Our findings suggest that, although professional development games typically draw on constructivist, collaborative mechanics (Huo 2019), the gaming mechanics in our case created situations where the speed of competing in the game appeared to override other aspects of the game, such as shared constitution of knowledge. Also, the game play setting might have created a speed pressure, because the teams were seated in the same room and were hence able to see when other teams finished the game.

Although our results suggest that the game helped students realize the importance of team effort and information sharing, it is necessary to point out the possible power asymmetries between team members. The attempt to complete the tasks as quickly as possible, and the teams' strong dependence on a few technologically experienced team members, limited the ability of other team members to explore the game. Huo (2019) argued that it is critical that constructivist games are "able to explore the story, environment, and mechanics under their own preference and curiosity" (p. 708). In our empirical example, team members with less game play and technology experience sometimes struggled to explore the game. This could have negative implications for team cohesion and team motivation. For some team members in our study, the lack of relevant technical skill or prior gaming experience created feelings of incompetence. Although the more skilled team members were keen to offer their help (Reich et al. 2013; Zhang et al. 2017), we observed that those with higher technical aptitude and experience in computer games occasionally ended up leading the others, who simply followed their instructions (on, for example, which button to press on the keyboard) rather than developing a deeper understanding of the team assignment and taking pleasure in discovering solutions for themselves.

This was partly caused by the teams' location in the same physical space, which allowed those familiar with gaming to intervene on behalf of their teammates. While true that this problem could be partly solved by playing the game purely online, we argue that it is important for game developers to carefully evaluate how the technology guides learning and whether it supports equal collaboration. There is an increasing expectation of 
digital skills in society (van Laar et al. 2020), and studies have found a positive relationship between technological proficiency and team effectiveness (Graham et al. 2020). Nevertheless, based on our findings, we believe that, in both research and practice, more attention is needed on the relationship between individuals' technical abilities and their capacity for collaborative learning (e.g., forming and instructing groups), and the influence of this relationship on the power relations emerging in the digital teamwork era.

The finding that students in our study emphasized and valued efficiency and competition has major implications for game-based pedagogy, particularly on the facilitator role. We emphasize the importance of collective debriefing both during and after the game. For example, in this case, students might have shifted from the competition mode and concentrated on communication and collective learning, had we reminded them of their importance in the middle of gameplay.

\section{Study limitations}

One study limitation is that the data were collected some years back. When applying the game in the course for the first time in 2013, it was a valuable addition to the course and its learning objectives. In 2017, we had to stop using the game, because its technology was no longer supported by our institution. Although Novicraft itself is no longer available because of technical changes and developments, we have continued to use games in the HRM course based on the positive experiences and outcomes, such as positive student feedback, and the enhanced interaction and collaboration among students. Moreover, the game also encouraged the lecturers to plan and develop a game of our own, designed specifically for our course's learning objectives. Collecting and analyzing student feedback on their course learning over the years has offered rich data for developing a new game, as well as for scholarly examination.

The educational games field has recently developed, with more variety and more technologically advanced versions now available in the market. However, we find that many of this study's findings provide valuable insights for university pedagogy. Kalmi et al. (2020) found that university faculty members hope to see more research on game use and their perceived benefits in university pedagogy. In our Finnish context, there is very little research available on game use in university teaching. Kalmi et al.'s (2020) survey in one Finnish university showed that most respondents had utilized gamification (71\%), but many felt insecure about technological issues and learning the game in advance. Our hands-on findings contribute to the advancement of game-based learning in a Finnish university context.

Another limitation involves the research design and playing the game in a computer classroom, where all players were located in the same physical place, close to one another. This highlights the importance of face-to-face contact, whereas many teams currently operate virtually rather than being in the same physical space. During the facilitator training, the game developers mentioned that it was possible to play the game online without being in the same physical space, but this might have required players to have more advanced collaboration and interaction skills. Communication, trust creation, and commitment play a crucial role in the functioning of virtual teams, where the roles of teamwork and leadership skills are especially important (Henttonen \& Blomqvist 2005). We acknowledge that playing the game online could have produced different learning experiences and students might have found other ways to collaborate and interact. However, our study shows how a simulation game enhances collaborative learning and teamwork skills in a traditional classroom setting. 


\section{Conclusion}

This study involved a pedagogical intervention in higher education. It combined the application of technology, through computer gaming, with the development of teamwork competencies. The study answered to research question: What were the students' experiences with, and key learning outcomes of collaborative learning? First, the study illustrated the benefits of using simulation games in undergraduate curriculums, including increased student interest and participation, higher group morale, and a greater awareness of teamwork (Beltrao \& Barcante 2016). The game provided a means for learning and analyzing teamwork skills, both as a member of a group and as a group leader. Second, the study highlighted the importance of teamwork skills and competencies in various types of problem-solving situations. It also demonstrated that students appreciate the "fun" aspect of learning through a game. We therefore encourage the use of games in undergraduate teaching to engage and inspire students. However, when answering the third and final research question, our study also revealed that students tend to equate team success with the speed of team performance; therefore, we suggest that future research focus on the effects this may have on collaborative learning.

Author contributions All authors have made substantial contributions to the conception, design of the study, and manuscript. ER and MK collected and analyzed the empirical data and were responsible of the results section. All authors read and approved the final manuscript.

Funding Open access funding provided by University of Jyväskylä (JYU). The authors declare that this research has not received any kind of funding from any institution or individual.

Data availability The datasets used and/or analyzed during the current study are available from the corresponding author on reasonable request.

\section{Declarations}

Conflict of interest The authors declare that they have no conflict of interest.

Open Access This article is licensed under a Creative Commons Attribution 4.0 International License, which permits use, sharing, adaptation, distribution and reproduction in any medium or format, as long as you give appropriate credit to the original author(s) and the source, provide a link to the Creative Commons licence, and indicate if changes were made. The images or other third party material in this article are included in the article's Creative Commons licence, unless indicated otherwise in a credit line to the material. If material is not included in the article's Creative Commons licence and your intended use is not permitted by statutory regulation or exceeds the permitted use, you will need to obtain permission directly from the copyright holder. To view a copy of this licence, visit http://creativecommons.org/licenses/by/4.0/.

\section{References}

Avry, S., Chanel, G., Bétrancourt, M., \& Molinari, G. (2020). Achievement appraisals, emotions and sociocognitive processes: how they interplay in collaborative problem-solving? Computers in Human Behavior, 107, 1-20. https://doi.org/10.1016/j.chb.2020.106267

Barker, L. J., Garvin-Doxas, K., \& Jackson, M. (2002). Defensive climate in the computer science classroom. In Proceedings of the 33rd SIGCSE technical symposium on computer science education (pp. 43-47).

Belbin, R. M. (1996). The coming shape of organization. Butterworth Heinemann. 
Beltrao, K. I., \& Barcante, L. C. (2016). Teaching principles and fundamentals of business excellence to undergraduate students through a game. Total Quality Management \& Business Excellence, 27(5-6), 681-698. https://doi.org/10.1080/14783363.2015.1043116

Brymann, A., \& Bell, E. (2011). Business research methods (3rd ed.). Oxford University Press.

Cobo, C. (2013). Mechanisms to identify and study the demand for innovation skills in world-renowned organizations. On the Horizon, 21(2), 96-106. https://doi.org/10.1108/10748121311322996

Cohen, K. J., \& Rhenman, E. (1961). The role of management games in education and research. Management Science, 7, 131-166. https://doi.org/10.1287/mnsc.7.2.131

Dawson, S. (2008). A study of the relationship between student social networks and sense of community. Educational Technology \& Society, 11(3), 224-238. https://doi.org/10.2307/jeductechsoci.11.3.224

Dawson, S., Tan, J. P. L., \& McWilliam, E. (2011). Measuring creative potential: using social network analysis to monitor a learners' creative capacity. Australasian Journal of Educational Technology, 27(6), 924-942. https://doi.org/10.14742/ajet.921

Dillenbourg, P. (1999). What do you mean by collaborative learning? In P. Dillenbourg (Ed.), Collaborative-learning: Cognitive and computational approaches (pp. 1-19). Elsevier.

Faria, A. J., Hutchinson, D., Wellington, W. J., \& Gold, S. (2008). Developments in business gaming: a review of the past 40 years. Simulation and Gaming, 40, 464-487. https://doi.org/10.1177/10468 78108327585

Feinstein, A. (2001). An assessment of the effectiveness of simulation as an instructional system. Journal of Hospitality \& Tourism Research, 25(4), 421-443. https://doi.org/10.1177/109634800102500 405

Feinstein, A. H., Mann, S., \& Corsun, D. L. (2002). Charting the experiential territory: clarifying definitions and uses of computer simulation, games, and role play. Journal of Management Development, 21(10), 732-744. https://doi.org/10.1108/02621710210448011

Felder, R. M., \& Brent, R. (2003). Designing and teaching courses to satisfy the ABET engineering criteria. Journal of Engineering Education, 92(1), 7-25. https://doi.org/10.1002/j.2168-9830.2003.tb00734.x

Felder, R. M., \& Brent, R. (2004). The ABC's of engineering education: ABET, Bloom's taxonomy, cooperative learning, and so on. In Proceedings of the 2004 American society for engineering education annual conference \& exposition (Vol. 1, pp. 1-36).

Fiore, S. M., Graesser, A., Greiff, S., Griffin, P., Gong, B., Kyllonen, P., \& Soulé, H. (2017). Collaborative problem solving: Considerations for the national assessment of educational progress. Washington, D. C.: National Center for Education Statistics. http://hdl.handle.net/10993/31897

García, M. G., López, C. B., Molina, E. C., Casas, E. E., \& Ruiz Morales, Y. A. (2016). Development and evaluation of the team work skill in university contexts are virtual environments effective? International Journal of Educational Technology in Higher Education, 13(5), 1-11. https://doi.org/ 10.1186/s41239-016-0014-1

Garrison, D. R., Anderson, T., \& Archer, W. (2001). Critical thinking, cognitive presence, and computer conferencing in distance education. American Journal of Distance Education, 15(1), 7-23. https:// doi.org/10.1080/08923640109527071

Gašević, D., Joksimović, S., Eagan, B. R., \& Shaffer, D. W. (2019). SENS: network analytics to combine social and cognitive perspectives of collaborative learning. Computers in Human Behavior, 92, 562-577. https://doi.org/10.1016/j.chb.2018.07.003

Graham, C. M., Daniel, H., \& Doore B. (2020). Millennial teamwork and technical proficiency's impact on virtual team effectiveness: Implications for. In Information Resources Management Association (Ed.), Five Generations and Only One Workforce: How Successful Businesses Are Managing a Multigenerational Workforce (pp. 186-209). Hershey PA: IGI Global

Hämäläinen, R. (2011). Using a game environment to foster collaborative learning: a design-based study. Technology, Pedagogy and Education, 20(1), 61-78. https://doi.org/10.1080/1475939X.2011.554010

Haythornthwaite, C. (2002). Building social networks via computer networks: creating and sustaining distributed learning communities. Building Virtual Communities CAmbridge: Cambridge University Press. https://doi.org/10.1017/CBO9780511606373.011

Henttonen, K., \& Blomqvist, K. (2005). Managing distance in a global virtual team: the evolution of trust through technology-mediated relational communication. Strategic Change, 14(2), 107-119. https://doi.org/10.1002/jsc. 714

Hofstede, G. (1980). Motivation, leadership, and organization: do American theories apply abroad? Organizational Dynamics, 9(1), 42-63. https://doi.org/10.1016/0090-2616(80)90013-3

Hsieh, H. F., \& Shannon, S. E. (2005). Three approaches to qualitative content analysis. Qualitative Health Research, 15(9), 1277-1288. 
Huo, Y. (2019). A Pedagogy-based framework for optimizing learning efficiency across multiple disciplines in educational games. International Journal of Information and Education Technology, 9(10), 704-709. http://www.ijiet.org/vo19/1290-JR358.pdf

Johnson, D. W., \& Johnson, R. T. (1999). Learning Together and Alone: Co-operative, Competitive and Individualistic Learning. Allyn \& Bacon.

Johnson, D. W., \& Johnson, R. T., et al. (2002). Cooperative Learning and Social Interdependence Theory. In R. S. Tindale (Ed.), Theory and Research on Small Groups Social Psychological Applications to Social Issues $p$ (pp. 9-35). Boston: Springer.

Joyce, W. B. (1999). On the Free-Rider Problem in Cooperative Learning. Journal of Education for Business, 74(5), 271-275. https://doi.org/10.1080/08832329909601696

Kalfa, S., \& Taksa, L. (2017). Employability, managerialism, and performativity in higher education: a relational perspective. Higher Education, 74, 687-699. https://doi.org/10.1007/s10734-016-0072-2

Kalmi, P., Jaskari, M.-M., \& Eronen, S. (2020). Pelillisyys innostamassa oppimaan: tuloksia kyselystä Vaasan yliopiston opetushenkilökunnalle. Vaasa: Vaasan yliopisto. http://urn.fi/URN:ISBN: 978-952-476-911-2

Karakas, F., Manisaligil, A., \& Sarigollu, E. (2015). Management learning at the speed of life: designing reflective, creative, and collaborative spaces for millennials. The International Journal of Management Education, 13, 237-248. https://doi.org/10.1016/j.ijme.2015.07.001

Kark, R. (2011). Games Managers Play: play as a form of leadership development. Academy of Management Learning and Education, 10(3), 507-527. https://doi.org/10.5465/amle.2010.0048

Kebritchi, M., \& Hirumi, A. (2008). Examining the pedagogical foundations of modern educational computer games. Computers \& Education, 51(4), 1729-1743. https://doi.org/10.1016/j.compedu.2008.05. 004

Kogler Hill, S. E. (2001). Team leadership. In P. G. Northouse (Ed.), Leadership: Theory and practice (2nd ed., pp. 161-187). Sage.

Lähteenmäki, S., Saarinen, E., Fischlmayr, I. C., \& Lainema, T. (2010). Virtual organizations. In B. Hossein (Ed.), Handbook of technology management (pp. 186-209). Wiley \& Sons.

Launonen, M., \& Kess, P. (2002). Team roles in business process re-engineering. International Journal of Production Economics, 77(3), 205-218. https://doi.org/10.1016/S0925-5273(00)00158-4

Leemkuil, H., \& De Jong, T. O. N. (2012). Adaptive advice in learning with a computer-based knowledge management simulation game. Academy of Management Learning \& Education, 11(4), 653-665. https://doi.org/10.5465/amle.2010.0141

Littleton, K., \& Häkkinen, P. (1999). Learning Together: Understanding the processes of Computer-based Collaborative Learning. In P. Dillenbourg (Ed.), Collaborative learning: cognitive and computational approaches (pp. 1-20). Pergamon.

Lohmann, G., Pratt, M. A., Benckendorff, P., Strickland, P., Reynolds, P., \& Whitelaw, P. A. (2019). Online business simulations: authentic teamwork, learning outcomes, and satisfaction. Higher Education, 77, 455-472. https://doi.org/10.1007/s10734-018-0282-x

Moreno, L., Gonzalez, C., Castilla, I., Gonzalez, E., \& Sigut, J. (2007). Applying a constructivist and collaborative methodological approach in engineering education. Computers \& Education, 49(3), 891915. https://doi.org/10.1016/j.compedu.2005.12.004

Northouse, P. G. (2016). Leadership: Theory and practice (7th ed.). Sage.

Novicraft. (2021). Retrieved May 27, 2021, from http://www.ludocraft.com/education/novicraft/

Pasin, F., \& Giroux, H. (2011). The impact of a simulation game on operations management education. Computers and Education, 57, 1240-1254. https://doi.org/10.1016/j.compedu.2010.12.006

Platt, S., Piepe, R., \& Smyth, J. (1988). Teams: A game to develop group skills. Gower Press.

Qian, M., \& Clark, K. R. (2016). Game-based learning and 21st century skills: a review of recent research. Computers in Human Behavior, 63, 50-58. https://doi.org/10.1016/j.chb.2016.05.023

Regueras, L. M., Verdu, E., Verdu, M. J., \& de Castro, J. P. (2011). Design of a competitive and collaborative learning strategy in a communication networks course. IEEE Transactions on Education, 54(2), 302-307.

Reich, S. M., Korobkova, K. A., Black, R. W., \& Sumaroka, M. (2013). "Hey! Can you show me how to do this?” Digital games mediating family interactions. In A. Burke, \& J. Marsh (Eds.) Children's Virtual play worlds: Culture learning and participation (pp. 1-17). New York: Peter Lang Publishing. https:// pdfs.semanticscholar.org/b138/5e2576b35ea6ba16a0e5327e047ad18fc193.pdf

Sawyer, J., \& Obeid, R. (2017). Cooperative and collaborative learning: Getting the best of both words. In R. Obeid, A. Schwartz, C. Shane-Simpson, \& P. J. Brooks (Eds.), How we teach now: The GSTA guide to student-centered teaching (pp. 163-177). 
Schindler, L. A., Burkholder, G. J., Morad, O. A., \& Marsh, C. (2017). Computer-based technology and student engagement: a critical review of the literature. International Journal of Educational Technology in Higher Education, 14(1), 1-28. https://doi.org/10.1186/s41239-017-0063-0

Schwartzman, R. (1997). Gaming serves as a model for improving learning. Education, 118(1), 9-17.

Siewiorek, A., Gegenfurtner, A., Lainema, T., Saarinen, E., \& Lehtinen, E. (2013). The effects of computersimulation game training on participants' opinions on leadership styles. British Journal of Educational Technology, 44(6), 1012-1035. https://doi.org/10.1111/bjet.12084

Siewiorek, A., \& Lehtinen, E. (2011). Exploring leadership profiles from collaborative computer gaming. International Journal of Leadership Studies, 6(3), 357-374.

Sitzmann, T. (2011). A meta-analytic examination of the instructional effectiveness of computer-based simulation games. Personnel Psychology, 64(2), 489-528. https://doi.org/10.1111/j.1744-6570.2011. 01190.x

Smith, B.L., \& MacGregor, J.T. (1992). What is collaorative learning? In A.S. Goodsell, M.R. Maher, V.Tinto, B.L. Smith, \& J. MacGregor (Eds.), Collaborative learning: A sourcebook for higher education. National Center on Postsecondary Teaching, Learning, and Assessment at Pennsylvania State University.

Tynjälä, P., \& Gijbels, D. (2012). Changing world: Changing pedagogy. In P. Tynjälä, M. L. Stenström, \& M. Saarnivaara (Eds.), Transitions and transformations in learning and education.Netherlands: Dordrecht, Springer.

van Knippenberg, D. (2017). Team innovation. Annual Review of Organizational Psychology and Organizational Behavior, 4, 211-233. https://doi.org/10.1146/annurev-orgpsych-032516-113240

van Laar, E., van Deursen, A. J. A. M., van Dijk, J. A. G. M., \& de Haan, J. (2020). Determinants of 21stCentury skills and 21st-Century digital skills for workers: a systematic literature review. SAGE Open. https://doi.org/10.1177/2158244019900176

Vandercruysse, S., Vandewaetere, M., \& Clarebout, G. (2012). Game-based learning: A review on the effectiveness of educational games. In M. M. Cruz-Cunha (Ed.), Handbook of research on serious games as educational business and research tools: Development and design, Hershey. IGI Global: PA.

Vandercruysse, S., Vandewaetere, M., Cornillie, F., \& Clarebout, G. (2013). Competition and student's perceptions in a game-based language learning environment. Educational Technology Research Development, 61, 927-950. https://doi.org/10.1007/s11423-013-9314-5

Vlachopoulos, D., \& Makri, A. (2017). The effect of games and simulations on higher education: a systematic literature review. International Journal of Educational Technology in Higher Education, 14(22), 1-33. https://doi.org/10.1186/s41239-017-0062-1

Wendel, V., Gutjahr, M., Göbel, S., \& Steinmetz, R. (2013). Designing collaborative multiplayer serious games. Education and Information Technologies, 18(2), 287-308. https://doi.org/10.1007/ s10639-012-9244-6

Wouters, P., van der Spek, E., \& van Oostendorp, H. (2009). Current practices in serious game research: A review from a learning outcomes perspective. In T. M. Connolly, M. Stansfield, \& L. Boyle (Eds.), Games-based learning advancements for multisensory human computer interfaces: Techniques and effective practices (pp. 232-250). Hershey, PA: IGI Global.

Zea, N. P., Sánchez, J. L. G., Gutiérrez, F. L., Cabrera, M. J., \& Paderewski, P. (2009). Design of educational multiplayer videogames: a vision from collaborative learning. Advances in Engineering Software, 40(12), 1251-1260. https://doi.org/10.1016/j.advengsoft.2009.01.023

Zhang, F., Kaufman, D., Schell, R., Salgado, G., Seah, E., \& Jeremic, J. (2017). Situated learning through intergenerational play between older adults and undergraduates. International Journal of Educational Technology in Higher Education, 14, 1-16. https://doi.org/10.1186/s41239-017-0055-0

Publisher's Note Springer Nature remains neutral with regard to jurisdictional claims in published maps and institutional affiliations.

Elina Rivari, PhD (Econ), M.A. is University Teacher in management and leadership and Pedagogical Director at the University of Jyväskylä, School of Business and Economics, Finland. Her main research interests include business ethics, and organizational innovativeness and creativity.

Marke Kivijärvi, D.Sc. (Econ. \& Bus.Adm.) works as Academy of Finland Postdoctoral Researcher at the University of Jyväskylä, School of Business and Economics, Finland. Her main research interests include gender and equality, and her current project examines gender in the video game industry. 
Anna-Maija Lämsä is Professor of Human Resource Management and Vice Dean at the University of Jyväskylä, School of Business and Economics, Finland. Her research interests are organizational ethics, gender in working life and business management education. 